\title{
ПРОБЛЕМА ЗАБОРОНИ СМЕРТНОӤ КАРИ В МІЖНАРОДНОМУ ПРАВІ
}

\author{
КИСІЛЬ Оксана Вікторівна - студентка першого курсу магістратури \\ факультету адвокатури Національного юридичного університету імені Ярослава \\ Мудрого \\ ORCID 0000000196456210 \\ УДК 341.1/8 \\ DOI 10.32782/EP.2021.2.21
}

\begin{abstract}
В статье проанализировано нарушение права на жизнь как фундаментального природного права человека и исследовано международнъе акть, которье касаются запрета смертной казни. Изучено вопрос отменъ данной меры наказания на международном уровне и въделено отношение разнъхх государств к этой проблеме. Опьт стран свидетельствует о том, ито больиинство развитьх государств отказались от самого жестокого и необратимого наказания, но остаются страны, которые продолжают ее использовать, тем самым нарушая общепринятье нормь и принципь морали. В статье предоставлено актуальную статистику государств, которье продолжают использовать смертную казнь и количество случаев ее применения.

Ключевъе слова: право на жизнь, смертная казнь, мера наказания, права человека, международнъе акть.
\end{abstract}

\section{Постановка проблеми}

Iз розвитком міжнародного співробітництва, усвідомленням того, що зневажливе, грубе ставлення до людського життя є дуже поширеним явищем, яке дійсно загрожує основам суспільства, порушує конституційні принципи та права і свободи громадян, проблема смертної кари перестає бути питанням лише внутрішньої юрисдикції держав, а й виходить на міжнародний рівень. Саме тому міжнародним співтовариством було розроблено низку міжнародно-правових актів, які стосуються питання смертної кари, обмежують її засто- сування і направлені на повне скасування такого виду покарання, які будуть розглянуті в цій статті.

Щороку неурядовою організацією «Amnesty International» збирається статистика грубих порушень прав людини. Так, за їі даними щонайменше 483 людини було страчено у 2020 році по всьому світу. Ці дані не включають страти в країнах, де інформація про смертну кару є державною таємницею або має обмежений доступ, зокрема, у Китаї, В'єтнамі, Північній Кореї та Сирії. У порівнянні з 2019 роком кількість страт скоротилася на $26 \%$, а порівняно з максимальним показником у 2015 році, коли було зафіксовано 1634 страти, - на 70 відсотків [1].

Крім цього, число зареєстрованих страт минулого року суттево скоротилося у Саудівській Аравії (з 184 за 2019 рік до 27-ми) та в Іраку (зі 100 до 45-ти). Не було зафіксовано страт минулого року в наступних країнах, які ще в 2019 року проводили їх: Бахрейн, Білорусь, Японія, Пакистан, Сінгапур та Судан. Проте, незважаючи на зменшення кількості страт минулого року, у Єгипті кількість таких покарань зросла утричі, Індія, Оман, Катар і Тайвань відновили застосування смертної кари. Адміністрація колишнього президента США Дональда Трампа в 2020 році після 17-річної перерви відновила страти на федеральному рівні і менш, ніж за півроку, стратила 10 людей [1]. Тож простежується тенденція не скасування найжорстокішого 


\section{Міжнародне право}

виду покарання, а навпаки, повернення до нього.

Отже, станом на квітень 2021 року зі 197 країн світу 108 держав скасували смертну кару за всі злочини, а 144 країни відмінили iii законодавчо або на практиці. Генеральна секретарка Amnesty International Аньєс Калламар відзначила: «Смертна кара - це огидне покарання, і те, що страти продовжуються у розпал пандемії, ще більше підкреслює притаманну цьому явищу жорстокість. Боротьба зі стратами була непростою справою і в кращі часи, але пандемія призвела до того, що багато людей в камері смертників не змогли отримати доступ до юридичної допомоги, і багато хто з тих, хто хотів надати підтримку, мав піддати своє здоров' я значному ризику, якого, утім, можна було уникнути. Застосування смертної кари в цих умовах $\varepsilon$ особливо кричущим посяганням на права людини» [1]. Тому, 3 огляду на вищезазначене, актуальність даної проблеми не викликає сумнівів, і, враховуючи нові світові виклики, пов'язані 3 поширенням пандемії, має бути найшвидше скасована повністю і безповоротно.

\section{Стан дослідження проблеми}

Тема смертної кари є досить популярною та важливою для вивчення. Багато науковців, юристів займалися дослідженням цієї проблеми, зокрема, обгрунтування застосування смертної кари аналізували у своїх роботах І.Й. Бойко, О. Б. Мезя6в, Б. Р. Тузмухамедов, Т. М. Фоміченко, Г. М. Вельямінов та інші. Окремі питання скасування цього інституту вивчали такі науковці:M.I. Бажанов, В. О. Карташкін, О.Ф. Кістяківський, Ю.О. Толстенко, М. М. Бірюков.

Метою і завданням статті є дослідження міжнародних актів, які стосуються питання смертної кари, аналіз цієї проблеми та визначення ставлення до цього явища у різних країнах світу.

\section{Виклад основного матеріалу дослідження}

У рамках Організації Об’єднаних Націй (далі - ООН) було розроблено перший в іс- торії міжнародних відносин універсальний акт, який проголосив право на життя, як фундаментальне право людини, - Загальну декларацію прав людини. Ї̈̈ було прийнято 10 грудня 1948 року у вигляді резолюції Генеральної Асамблеї ООН. У статті 3 Загальної декларації прав людини закріплено, що «кожна людина має право на життя, на свободу і на особисту недоторканність», у статті 5, що «ніхто не повинен зазнавати тортур, або жорстокого, нелюдського, або такого, що принижуе його гідність, поводження і покарання» [2]. Таким чином, підкреслюється значущість людини, ії життя, необхідність дотримуватися і не нехтувати іiі правами. Зважаючи на рекомендаційний характер резолюції, норми, закріплені в ній, вважаються лише бажаними для держав-членів ООН. Проте, варто враховувати те, що в міжнародному праві важливу роль відіграє також звичай, який формується в результаті практики і з часом може бути визнаний державами загальнообов'язковим. Саме тому проголошені в Загальній декларації прав людини основні права на сьогодні вважаються звичаєвими нормами міжнародного права, яких повинні дотримуватися всі держави, на рівні з договірними. Закріплене в цьому акті право на життя безпосередньо пов'язане з її невід'ємним аспектом - смертною карою.

Міжнародний пакт про громадянські i політичні права гарантуе право кожного на життя. Так, ч.1 ст.6 закріплює: «Право на життя є невід'ємне право кожної людини. Це право охороняється законом. Ніхто не може бути свавільно позбавлений життя». Відповідно до ч. 2, 5 цієї статті: «Смертний вирок може виноситися тільки за найтяжчі злочини, страта не призначається особам, молодше вісімнадцяти років і вагітним жінкам» [3]. Відповідно до ст. 1-2 Другого факультативного протоколу до Міжнародного пакту про громадянські та політичні права, прийнятого резолюцією Генеральної Асамблеї ООН 44/128, «жодна особа, що знаходиться під юрисдикцією держави-учасниці Протоколу, не буде страчена... кожна держава-учасниця вживає всіх необхідних заходів задля скасування смертної кари в рамках своєї юрисдикції» [4]. 
Крім цього, у статті 37 Конвенції про права дитини 1989 р. звертається увага, що «держави-учасниці повинні забезпечувати, щоб смертна кара не призначалася за злочини, вчинені особами, молодшими 18 років» $[5]$.

Окрім універсальних міжнародно-правових актів з прав людини, заборона смертної кари або ії̈ обмеження закріплені у регіональних документах. Рада Европи, до складу якої входять 47 держав-учасниць, відіграла ключову роль у просуванні прав людини в Европі. Так, Конвенція про захист прав людини та основоположних свобод (далі - СКП А), прийнята Радою Европи у 1950 р., у статті 2 встановлює, що «право кожного на життя охороняється законом. Нікого не може бути умисно позбавлено життя інакше, ніж на виконання смертного вироку суду, винесеного після визнання його винним у вчиненні злочину, за який закон передбачає таке покарання» [6]. Тобто у самій Конвенції не передбачено чітко закріпленої заборони на застосування смертної кари. Протокол № 6 до ЄКПА від 28 квітня 1983 р. у ст. 1 визначив, що «смертна кара скасовується. Нікого не може бути засуджено до такого покарання або страчено». Ст. 2 Протоколу закріплює застосування смертної кари під час війни: «Держава може передбачити у своєму законодавстві смертну кару за діяння, вчинені під час війни або невідворотної загрози війни; таке покарання застосовується лише у випадках, передбачених цим законодавством i згідно 3 його положеннями. Держава повідомляє Генерального секретаря Ради Европи про відповідні положення цього законодавства» [7]. Протокол № 13 до ЕКП прийнятий 5 травня 2002 р., забороняє застосовувати смертну кару за будь-яких обставин як у мирний, так і у воєнний період. «Жодних відступів та застережень стосовно положень Протоколу не допускається» [8].

У практиці Европейського суду з прав людини висвітлюються принципові моменти реалізації права на життя та безпосередньо з ним пов'язаної смертної кари. Так, рішення Европейського суду з прав людини у справі «Сьорінг проти Сполученого Королівства» стало поштовхом до зміни правової позиції щодо смертної кари [9]. Після вирішення справи «Сьорінг» відбулася майже загальна відмова від смертної кари в Европі, всі договірні держави підписали Протокол № 6 і майже всі (окрім Російської Федерації) 3 них ратифікували його [11].

У більшості справ щодо смертної кари, які розглядаються Европейським судом 3 прав людини, іiі застосування визначають таким, що принижує гідність особи і є нелюдським. Так, Суд у справі Абдули Оджалана зазначив, що застосування смертної кари повинно підпорядковуватись принципу, за яким «ніхто не може бути свавільно позбавлений життя». Як стаття 6 Міжнародного пакту про громадянські та політичні права, так і стаття 4 Американської Конвенції про права людини вимагають суворого дотримання правової процедури та обмежують можливість застосування цього покарання лише «найбільш серйозними злочинами». Так як виконання смертної кари є непоправним, від держав вимагається найжорсткіше та найретельніше дотримання судових гарантій, аби такі гарантії не були порушені, та в результаті, щоб людське життя не позбавлялося свавільно [10].

Прийняття вищезгаданих протоколів до Конвенції про захист прав людини i основоположних свобод, а також відповідна практика Европейського суду з прав людини слугували остаточному вирішенню проблеми смертної кари в європейському регіоні. Водночас, це питання залишається вкрай актуальним для інших держав, національне законодавство яких не містить не просто заборони, але й принаймні чітких правил та процедури призначення й застосування смертної кари.

Так, Конституційний Суд Аитви визначив, що необхідно поєднувати кримінальне покарання із збереженням людяності, поваги до особи та ії гідності, та, по-друге, мета такого покарання має відновлювати порушений порядок та гарантувати безпеку людей. Суд наголошує: «Основним принципом кримінального права є принцип, за яким покарання, визначене в ньому, не повинно бути жорстокішим, аніж необхідно для перевиховання особи, котра вчинила 


\section{Міжнародне право}

злочин, аби така особа не вдалася до злочинних дій у майбутньому» [11]. Об'єктивно можна сказати, що в більшості сама по собі смертна кара не виконує превентивної чи профілактичної функції у сфері боротьби зі злочинністю [12].

Це означає, що смертна кара, яка виключає можливість перевиховання особи, позбавляє остаточно іiї прав, зокрема права на повагу до гідності, є несумісною із закріпленими в універсальних та регіональних актах положеннями про права людини.

Крім цього, варто звернути увагу, що набуває загального визнання правило, відповідно до якого у справах, у яких злочинцями $є$ неповнолітні, застосування до них смертних вироків забороняється. Думка більшості суддів Верховного суду США у справі «Roper v. Simmons» сформульована так: «Коли неповнолітній злочинець вчиняє тяжкий злочин, штат може позбавити його більшості свобод, але штат не може позбавляти його життя та потенціалу досягнути дорослого розуміння своєї власної людяності». Проте не всі країни погоджуються із цією думкою. Так, в Ірані, Пакистані, Саудівській Аравії, Смені дозволено страчувати неповнолітніх у мирний час, що є грубим порушенням норм міжнародного права. Також в Ірані зустрічалися випадки страти 3-річних дітей разом 3 батьками. Тому можна зазначити, що обмеження щодо віку осіб, які засуджуються до смертної кари, встановлені не у всіх країнах [13].

Окрім страти неповнолітніх гостро постало питання про можливість застосування смертної кари щодо психічнохворих. Аише у 2002 році у справі «Penry v. Lynaugh» Bepховний суд США дійшов до висновку, що страта психічнохворих становить жорстоке та незвичне покарання. Психічна хвороба знижує рівень розуміння злочинцем своїх дій, зменшує ступінь вини, навіть якщо він може відрізняти добре від поганого [14].

За даними Міжнародної Амністії, застосування страти у світі дуже скоротилося та значно звузилося коло діянь, за які призначається смертна кара [15]. У деяких країнах страта передбачена за злочини проти держави, власності, застосування зброї, торгівлю людьми, підбурювання до само- губства, проте смертні вироки здебільшого ухвалюються тільки за умисне вбивство за обтяжуючих обставин (наприклад, Японія). У Китаї смертний вирок можуть винести за аж 53 злочини, до переліку яких входять сепаратизм, державна зрада, шпигунство, збройне повстання, згвалтування, торгівля людьми, корупція, привласнення державного майна, виготовлення та продаж наркотичних засобів тощо. У Пакистані перебачено смертне покарання за 27 злочинів: згвалтування, позашлюбні відносини, контрабанда наркотичних засобів, богохульство, що визнається одним із найсерйозніших злочинів та інші [16]. У деяких країнах застосовується поняття «черга смертників». Це означає, що після призначення особі покарання у вигляді позбавлення життя, справа надсилається одразу ж до апеляційної інстанції, і це призводить до того, що засуджені роками чекають на вирішення своєї долі. Так, існував випадок, коли ув'язнений 37 років чекав страти і помер своєю смертю (США) [11].

\section{Висновки}

Підсумовуючи вищевказане, можна зробити висновок, що одним із основних принципів міжнародного права 6 повага до прав і свобод людини, а право на життя справедливо визнається найважливішим 3-поміж таких прав. Як зазначає H.I. Матузов, «право на життя - перше фундаментальне природне право людини, без якого всі інші права втрачають сенс» [17]. Проте, законодавством значної кількості країн передбачено смертну кару, що зводить нанівець забезпечення державою права на життя кожної особи. Виходячи із загальнолюдських принципів та позицій моралі, смертна кара $\epsilon$ недопустимою, це крок у минуле для всього суспільства. Будь-який вид покарання повинен відповідати меті покарання. А ціллю покарання є саме перевиховання особи, а не їі знищення. У будьякій правовій державі на першому місці має знаходитись людина. Держава повинна гарантувати право на життя та шанувати їі гідність. Визнаючи людину, її життя абсолютною цінністю, усі країни без винятку мають скасувати цей вид покарання. 
Як бачимо, проблема смертної кари не втрачає своєї актуальності й у XXI столітті. Зважаючи на виключно серйозний та непоправний характер такої міри покарання, необхідно, аби міжнародне співтовариство впливало всіма можливими засобами на вирішення цієї проблеми.

\section{Лiтepaтypa}

1. Amnesty International: за рік у світі зменшилася кількість страт. Made for minds.URL: https://www.dw.com/uk/amnestyinternational-za-rik-u-sviti-zmenshylasiakilkist-strat/a-57274654 (дата звернення: 23.04.2021).

2. Загальна Декларація прав людини: Декларація ООН від 10.12.1948 р. №995 015. Законодавство украӥни: вебcaŭm. URL: http://zakon.rada.gov.ua/laws/ show/995_015 (дата звернення: 03.04.2021).

3. Міжнародний пакт про громадянські і політичні права : Пакт ООН від 16.12.1966 р. № 995_043. Законодавство украӥни: веб-сайт. URL: http://zakon.rada. gov.ua/laws/show/995_043 (дата звернення: 03.04.2021)

4. Другий факультативний протокол до Міжнародного пакту про громадянські та політичні права, що стосується скасування смертної кари, прийнятий резолюцією Генеральної Асамблеї ООН 44/128 від 15 грудня 1989 року. URL: https://zakon.rada. gov.ua/laws/show/995 187\#top (дата звернення: 24.04.2021)

5. Конвенція про права дитини, прийнятий резолюцією Генеральної Асамблеї ООН від 20 листопада 1989 року. URL: https://zakon.rada.gov.ua/laws/ show/995 021\#Text (дата звернення: 23.04.2021)

6. Конвенція про захист прав людини та основоположних свобод : Конвенція від 04.11.1950 р. № 995_004. Законодавство украӥни: веб-сайт. URL: http://zakon.rada. gov.ua/laws/show/995_004 (дата звернення: 03.04.2021)

7. Протокол № 6 до Конвенції про захист прав і основоположних свобод людини, який стосується скасування смертної кари : Протокол від 28.04.1983 р. № 6. 3aконодавство Украйни: веб-сайт. URL: http:// zakon.rada.gov.ua/laws/show/994_802 (дата звернення: 04.04.2021)

8. Протокол №13 до Конвенції про захист прав і основоположних свобод лю- дини, який стосується скасування смертної кари за всіх обставин : Протокол від 03.05.2002 р. № 13. Законодавство України: веб-сайт. URL: http://zakon.rada.gov.ua/laws/ show/994_180 (дата звернення: 05.04.2021)

9. Серинг (Soering) против Соединенного Королевства: Решение Европейского суда по правам человека от 7 июля 1989 г.: HUDOC / European Court of Human Rights. URL:

h t t p :// w w w. echr.ru/d ocuments / doc/2461433/2461433.htm (дата звернення: $06.04 .2021)$

10. «Дело «Оджалан (ocalan) против Турции»: Постановление Европейского суда по правам человека от 12.05.2005: HUDOC / European Court of Human Rights. URL:

https://www.lawmix.ru/abrolaw/5263 (дата звернення: 05.04.2021)

11. Шевчук С. Судовий захист прав людини: практика Європейського Суду з прав людини у контексті західної правової традиції / С.Шевчук - К.: Реферат, 2006. - 700 с.

12. Толстенко Ю. О. Проблема смертної кари у міжнародному праві / Ю. О. Толстенко // Права людини і демократія : зб. наук. ст. за матеріалами наук. конф., м. Харків, 15 трав. 2018 р. - Харків, 2018. - C. 165-169. URL:

h t t p s : / / d s p a c e.n lu.ed u.u a / bitstream/123456789/15155/1/Tolstenko.pdf

13. Gregg v. Georgia, Proffitt v. Florida, Roper v. Simmons, Penry v. Lynaugh, and Roberts v. Louisiana: Decision of US Supreme Court. 1976 № 428 U. S. 153.

14. Бойко В. «Ми прийдемо до заміни смертної кари»// Голос України - 1997. 9 серпня. - C.6

15. Amnesty International зафіксувала найнижче число страт у світі за останні 10 років. Amnesty International. URL: https://www. amnesty.org.ua/smertna-kara-2019/

16. За які злочини засуджують до смертної кари у різних країнах світу. ТСH. URL: https://tsn.ua/svit/smertelna-in-yekciyarozstril-ta-povishennya-de-ta-chomu-dosistrachuyut-lyudey-1325481.html

17. Бирюков М.М. Международное право / М.М. Бирюков // ред. А.А. Ковалева, С.В. Черниченко. - М., Омега- $\lambda, 2006$. 209 c. 


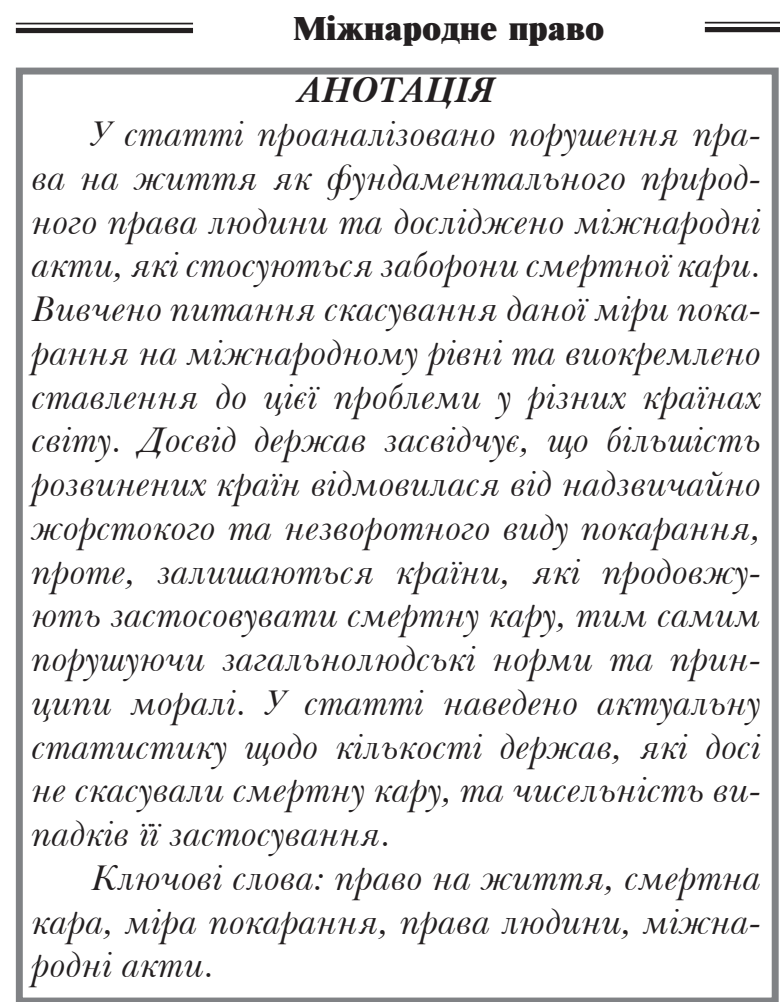

\section{THE PROBLEM OF THE PROHIBITION OF THE DEATH PENALTY IN INTERNATIONAL LAW}

A significant number of international instruments fix the right to life and proclaim the prohibition of arbitrary deprivation. The right to life, which is the basis of all other human rights, is directly associated with the death penalty. The article analyzes the violation of the right to life as a fundamental natural human right and researches international acts concerning the prohibition of the death penalty. The purpose of all adopted international acts is to achieve and ensure the inviolability of fundamental human rights and the adoption of appropriate norms on the non-application of the death penalty by all countries of the world. The article also examines the abolition of this measure of punishment at the international level and highlights the attitude to this problem in different countries. The experience of states shows that most developed countries have renounced extremely cruel and irreversible punishment, but there are still countries that continue to use the death penalty, thereby violating universal norms and principles of morality. The article presents current statistics on the number of states that have not yet abolished the death penalty, and the number of cases of its use. Attention is also drawn to the most important decisions of the European Court of Human Rights on this issue and analyzed the problem of execution of certain categories of persons (minors, persons with mental disorders). All these issues remain relevant at the present stage and in the midst of the pandemic become even more important and require more attention. The severity of this punishment and its cruelty require the provision of quality and effective legal assistance to convicts, which is much more difficult during the spread of the epidemic. The existence of this phenomenon has a profound effect on the development of all mankind and must be resolved as soon as possible in favor of saving human life and re-education of the person by other, less cruel means.

Key words: the right to life, death penalty, type of punishment, human rights, international acts. 